\title{
HUBUNGAN PENGETAHUAN TENTANG HIV/AIDS DENGAN STIGMA WARGA USIA SUBUR PADA ODHA DI DESA PONDOK KELOR KECAMATAN PAITON KABUPATEN PROBOLINGGO
}

\author{
Iit Ermawati ${ }^{1}$, Mega Silvian Natalia ${ }^{2)}$, Nova Hikmawati ${ }^{3)}$ \\ ${ }_{1}$ Program Studi DIII Kebidanan Stikes Hafshawaty Pesantren Zainul Hasan, Probolinggo, Indonesia \\ ${ }_{2}$ Program Studi S1 Kebidanan Stikes Hafshawaty Pesantren Zainul Hasan, Probolinggo, Indonesia \\ ${ }_{3}$ Program Studi Pendidikan Profesi Bidan Stikes Hafshawaty Pesantren Zainul Hasan, Probolinggo, Indonesia \\ email: iit.ermawati83@gmail.com
}

\begin{abstract}
Abstrak
Tujuan keenam dari MDGs yaitu menangani berbagai penyakit menular paling berbahaya. Pada urutan teratas adalah Human Immune Deficiency Virus (HIV), yaitu virus penyebab Aquired Immune Deficiency Virus Syndrome (AIDS), Stigma dan diskriminasi terhadap ODHA masih sering terjadi di berbagai tingkat lingkungan. Faktor yang cukup penting adalah kebijakan yang dinilai masih kurang sosialisasi dan sering berlawanan dengan implementasinya di lapangan. Di Kabupaten Probolinggo, Kecamatan Paiton berada di urutan tertinggi sebagai epidemi HIV/AIDS. Tujuan umum penelitian ini untuk mengetahui hubungan tingkat pengetahuan tentang HIV/AIDS dengan stigma warga usia subur pada ODHA di Desa Pondok Kelor Kecamatan Paiton Kabupaten Probolinggo. Penelitian ini merupakan penelitian analitik dengan rancangan bangun adalah crossectional. Populasi adalah semua ibu usia produktif (21-44 tahun) di Desa Pondok Kelor Kecamatan Paiton Kabupaten Probolinggo. Teknik pengambilan sampel menggunakan Simple Random Sampling. Sampel adalah sebagian warga usia produktif di Desa Pondok Kelor Kecamatan Paiton sebesar 150 orang. Pengumpulan data menggunakan kuesioner serta dianalisis secara univariat, bivariat. Hasil penelitian ini menunjukkan bahwa ada hubungan tingkat pengetahuan tentang HIV/AIDS dengan stigma masyarakat pada ODHA di Desa Pondok Kelor Kecamatan Paiton Probolinggo.
\end{abstract}

Kata kunci: pengetahuan, hiv, AIDS, stigma, ODHA

\begin{abstract}
The MDGs' sixth target is to combat the world's most dangerous infectious diseases. The Human Immune Deficiency Virus (HIV), which causes the Acquired Immune Deficiency Virus Syndrome (AIDS), is at the top of the list. Stigma and prejudice towards PLWHA are still prevalent at many levels of society. The policy, which is believed to be poor in socialization and frequently contradicts its implementation in the field, is a significant component. Paiton District is the most affected by the HIV/AIDS epidemic in Probolinggo District. The overall goal of this research was to see if there was a correlation between HIV/AIDS knowledge and stigma among women of childbearing age in Pondok Kelor Village, Paiton District, Probolinggo Regency. This study has a cross-sectional design and is an analytic investigation. Pondok Kelor Village, Paiton District, Probolinggo Regency, with a population of all mothers of working age (21-44 years). Simple Random Sample was utilized as the sampling method. In Pondok Kelor Village, Paiton District, 150 persons of working age were sampled. Data is collected via a questionnaire and evaluated using univariate and bivariate analysis. The results of this study indicate that there is a correlation between the level of knowledge about HIVIAIDS with community stigma on PLWHA in Pondok Kelor Village, Paiton District, Probolinggo.
\end{abstract}

Keywords: knowledge, HIV, AIDS, stigma

\section{PENDAHULUAN}

MDGs tujuan keenam yaitu menangani berbagai penyakit menular paling berbahaya. Pada urutan teratas adalah Human Immune
Deficiency Virus (HIV), yaitu virus penyebab Aquired Immune Deficiency Virus Syndrome (AIDS), penyakit ini dapat membawa dampak yang menghancurkan sistem kekebalan tubuh manusia, sehingga mempengaruhi kesehatan 
masyarakat serta terhadap negara keseluruhan (Pusdiklatnakes Kemenkes RI, 2013).

Di Indonesia jumlah penduduk yang hidup dengan virus HIV diperkirakan antara 172.000 dan 219.000, sebagian besar adalah laki-laki. Jumlah itu merupakan $0,1 \%$ dari jumlah penduduk. Menurut Komisi Penanggulangan AIDS Nasional (KPA), sejak 1987 sampai Juni 2008, tercatat 12.686 kasus AIDS, 2.479 diantaranya telah meninggal. ODHA (orang dengan HIV/AIDS) yang menjangkau layanan sampai tahun 2009 secara kumulatif adalah 43.118. Sementara proyeksi jumlah ODHA pada tahun 2009 berdasarkan data 2006 adalah 314.500. Tampak bahwa cakupan layanan masih jauh dari yang diharapkan. Terlebih Indonesia telah mengikatkan diri dalam kesepakatan global yaitu Universal Access. Untuk memberikan akses pencegahan, pengobatan, perawatan serta dukungan bagi semua ODHA yang membutuhkan pada tahun 2010.

Jumlah penderita HIV/AIDS di kabupaten Probolinggo terus bertambah hingga akhir November 2013 dengan jumlah penderita HIV/AIDS mencapai 623 penderita yang terdiri dari 361 laki-laki dan 262 perempuan. Dari jumlah tersebut, 416 penderita masih hidup dan sisanya 176 penderita sudah meninggal. Penderita didominasi usia reproduktif antara 21-44 tahun yang mencapai $72,8 \%$ atau sekitar 451 penderita. Di kabupaten Probolinggo, kecamatan Paiton berada di urutan tertinggi sebagai epidemi HIV/AIDS (Komisi penaggulangan AIDS (KPA)., 2014)

Berdasarkan hasil penelitian didapatkan mayoritas masyarakat mempunyai pengetahuan cukup dengan stigma terhadap ODHA sedang yaitu 55,2\%. Dan paling sedikit adalah masyarakat dengan pengetahuan baik memiliki stigma terhadap ODHA yang kurang yaitu 3,5\%. Dari data tersebut menunjukan bahwa ada hubungan tingkat pengetahuan tentang HIV/AIDS dengan stigma masyarakat pada ODHA di Desa Pondok Kelor Kecamatan Paiton Probolinggo.

Menurut Nyblade et al. (2009) mengungkapkan bahwa lingkungan dengan zero stigma and discrimination membantu ODHA untuk mendapatkan hak-hak azasinya terutama dalam pengambilan keputusan dan berfungsi optimal dalam kehidupan sosial. Menurut Busza
(1999) dalam literatur review menyatakan bahwa populasi rawan pun merasa takut untuk menjalani tes diagnostik disebabkan oleh ancaman stigma dan diskriminasi. Hal ini menjadikan penghalang bagi ODHA dan populasi rawan untuk menjangkau ketersediaan pelayanan kesehatan.

Stigma dan diskriminasi terhadap ODHA masih sering terjadi di berbagai tingkat lingkungan. Faktor yang cukup penting adalah masih kurangnya sosialisasi dan sering berlawanan dengan implementasinya di lapangan. Tujuan penelitian ini adalah untuk mengetahui hubungan tingkat pengetahuan tentang HIV/AIDS dengan stigma warga usia subur pada ODHA di Desa Pondok Kelor Kecamatan Paiton Kabupaten Probolinggo

\section{METODE PENELITIAN}

Penelitian ini merupakan penelitian analitik yang menjelaskan hubungan antar variabel, menggunakan alat bantu berupa kuesioner untuk mengukur setiap variabel yang diteliti. Rancang bangun penelitian ini adalah crossectional. Variabel penelitian diukur dalam suatu waktu sehingga diperoleh hubungan pengetahuan tentang HIV/AIDS dengan stigma masyarakat terhadap ODHA. Jumlah sampel sebanyak 150 warga usia produktif dengan teknik pengambilan sampel yaitu teknik Simple Random Sampling di Desa Pondok Kelor KecamatanPaiton Probolinggo. Analisis data dilakukan secara komputerisasi dengan program SPSS for Windows 17.00 menggunakan uji Spearman's Rho.

\section{HASIL DAN PEMBAHASAN}

Hasil penelitian menginformasikan bahwa dari 150 responden dalam penelitian ini sebagian besar berusia 21-30 tahun (51\%), dengan pendidikan terakhir sebagian adalah SMU (42\%), pekerjaan sebagian adalah ibu rumah tangga $(35 \%)$. Sebagian responden mempunyai pengetahuan yang cukup tentang HIV/AIDS (48\%) dan sebagian besar mempunyai stigma yang tinggi (57\%).

Berikut disajikan data hubungan tingkat pengetahuan tentang HIV/AIDS dengan stigma masyarakat pada ODHA. 
Iit Ermawati dkk., Hubungan Pengetahuan tentang HIV/AIDS dengan Stigma Warga Usia Subur pada ODHA di Desa Pondok Kelor Kecamatan Paiton Kabupaten Probolinggo

Tabel 1. Tabel Silang Hubungan Tingkat Pengetahuan tentang HIV/AIDS dengan Stigma Masyarakat pada ODHA

\begin{tabular}{ccccccccc}
\hline \multirow{2}{*}{ Pengetahuan } & \multicolumn{10}{c}{ Stigma } \\
\cline { 2 - 10 } & Kurang & \% & Sedang & \% & Tinggi & \% & Jml & \% \\
\hline Baik & 6 & 40 & 11 & 22,4 & 3 & 3,5 & 20 & 13,3 \\
Cukup & 8 & 53,3 & 27 & 55,2 & 37 & 43 & 72 & 48 \\
Kurang & 1 & 6,7 & 11 & 22,4 & 46 & 53,5 & 58 & 38,7 \\
\hline Total & 15 & 100 & 49 & 100 & 86 & 100 & 150 & 100 \\
\hline
\end{tabular}

Tabel 1 menginformasikan bahwa ada kecenderungan semakin baik pengetahuan masyarakat maka akan semakin rendah stigma masyarakat pada ODHA. Hasil uji statistik diperoleh $\mathrm{P}$ value $0,000<\alpha 0,05$ sehingga ada hubungan yang signifikan antara tingkat pengetahuan tentang HIV/AIDS dengan stigma masyarakat pada ODHA.

\section{Identifikasi Tingkat Pengetahuan tentang HIV/AIDS pada warga usia produktif}

Berdasarkan hasil penelitian yang didapat pada identifikasi tingkat pengetahuan tentang HIV/AIDS di Desa Pondok Kelor Kecamatan Paiton Kabupaten Probolinggo, didapatkan hasil bahwa mayoritas masyarakat atau warga usia produktif mempunyai pengetahuan tentang HIV/AIDS yang relatif cukup. Bahkan untuk yang mempunyai tingkat pengetahuan baik masih terbilang sedikit.

Penelitian ini sejalan dengan penelitian Shaluhiyah et al. (2015), yang menyimpulkan bahwa rata-rata pengetahuan remaja tentang HIV/AIDS pada tingkat baik adalah hanya sedikit yaitu $37 \%$.

Menurut Notoatmodjo (2012), yang dimaksud tingkat pengetahuan yaitu terdiri dari tahu (know), memahami (comprehension), aplikasi (application), analisis (analysis), sintesis (synthesis) dan evaluasi (evaluation). Tahu (know) adalah suatu kemampuan mengingat suatu materi yang dipelajari sebelumnya. Tahu merupakan tingkat pengetahuan yang paling rendah. Kata kerja untuk mengukur tingkat pengetahuan ini adalah menguraikan, mengidentifikasikan, menyatakan dan kata kerja lain yang sesuai, misalnya ibu dapat menyebutkan tentang HIV/AIDS.

Memahami (comprehension) merupakan suatu kemampuan untuk menjelaskan secara benar tentang objek yang diketahui, serta dapat menginterprestasikan materi tersebut secara benar. Orang yang telah memahami objek tertentu harus mampu menjelaskan, menyebutkan contoh, menyimpulkan dan memprediksi objek yang dipelajari, contoh: ibu dapat menjelaskan tanda dan gejala HIV/AIDS.

Aplikasi (application) adalah suatu kemampuan untuk menggunakan materi yang telah dipelajari pada situasi-situasi dan kondisi yang sebenarnya, misalnya: ibu dapat mengaplikasikan tindakan pencegahan dan tata cara penularan HIV/AIDS. Analisis (analysis) adalah suatu kemampuan untuk menjabarkan materi atau suatu objek dalam komponen-komponen yang berada dalam suatu struktur organisasi yang saling berkaitan antara satu dan yang lain. Kemampuan menganalisis dapat dilihat dari penggunaan kata kerja, contoh: menggambarkan, membedakan, memisahkan, mengelompokkan dan lain-lain.

Sintesis (synthesis) menunjuk kepada suatu kemampuan meletakkan atau menghubungkan bagian-bagian di dalam suatu bentuk keseluruhan yang baru, contoh: dapat merencanakan, meringkas, menyesuaikan, terhadap suatu rumusan yang telah ada. Evaluasi (Evaluation) berkaitan dengan kemampuan untuk melakukan penilaian terhadap suatu objek.

Pengetahuan warga usia reproduktif di Desa Pondok Kelor Kecamatan Paiton Kabupaten Probolinggo tergolong masih cukup. Hal ini bisa dikarenakan masyarakat pada desa tersebut, tingkat pengetahuannya masih sebatas tahu, belum sampai dengan tahap memahami atau bahkan analisis. Dengan pengetahuan yang cukup, ternyata stigma masyarakat terhadap ODHA masih kurang. Hal ini diakibatkan oleh kurangnya informasi dan kekhawatiran masyarakat yang masih terlalu tinggi terhadap ODHA sehingga masyarakat dengan pengetahuan yang cukup ternyata masih mempunyai stigma yang tinggi. Hal ini juga bisa 
disebabkan oleh tingkat pendidikan mayoritas warga hanya sampai jenjang SMA

\section{Identifikasi Stigma Masyarakat pada ODHA}

Untuk stigma masyarakat pada ODHA didapatkan hasil identifikasi bahwa sebagian besar stigma masyarakat pada ODHA adalah tinggi yaitu $57 \%$, dan untuk stigma masyarakat pada ODHA kategori kurang terbilang masih sedikit.

Stigma adalah suatu ancaman, sifat atau karakteristik bahwa masyarakat menerima ketidaknyamanan yang sangat tinggi. Mendapat ancaman membuat seseorang menerima stigmatisasi. Stigmatisasi adalah tindakan memvonis seseorang sebagai buruk moral (Kementerian Kesehatan Republik Indonesia, 2013).

Menurut penelitian Shaluhiyah et al. (2015), responden dengan keluarga yang memberikan stigma memiliki kemungkinan memberikan stigma terhadap ODHA empat kali lebih besar dibandingkan responden yang keluarganya tidak memberikan stigma. Demikian juga responden yang berpersepsi negatif terhadap ODHA memiliki kemungkinan memberikan stigma dua kali lebih besar dibandingkan yang berpersepsi positif. Faktor sikap tetangga dan tokoh masyarakat terhadap ODHA juga berhubungan signifikan dengan stigma responden terhadap ODHA. Sehingga dapat dikatakan bahwa sikap keluarga dan persepsi responden terhadap ODHA merupakan faktor yang berpengaruh pada munculnya stigma terhadap ODHA.

Hal-hal yang disebabkan oleh stigma adalah sebagai berikut: 1) perubahan pandangan terhadap seseorang (social identity), 2) penolakan atau penurunan kesempatan interaksi sosial, 3) kesempatan berkurang misal: perumahan, pekerjaan dan pelayanan kesehatan, 4) perasaan malu dan membenci diri pada penilaian masyarakat, 5) memungkinkan pengurangan kualitas hidup seseorang.

Penelitian Mutahar et al. (2011) mengatakan bahwa berdasarkan pertanyaan stigma terhadap ODHA, diketahui bahwa $66,6 \%$ responden tidak akan membeli sayuran segar dari penjual atau petani yang diketahui terinfeksi HIV/AIDS. Seperti diketahui orang yang terinfeksi HIV (penjual sayuran) akan mengalami infeksi oportunistik yang terkait dengan infeksi HIV. Hal ini kemungkinan yang menyebabkan orang enggan membeli sayuran karena takut tertular infeksi tersebut

Di Desa Pondok Kelor Kecamatan Paiton Kabupaten Probolinggo stigma masyarakat pada ODHA masih kurang. Hal ini menunjukkan bahwa masyarakat di daerah tersebut masih kurang nyaman atau merasa khawatir terhadap HIV/AID, sehingga membutuhkan proses untuk memahami atau menerima masalah atau kasus tersebut.

\section{Hubungan Tingkat Pengetahuan tentang HIV/AIDS dengan Stigma Masyarakat pada ODHA}

Dari tabel silang dapat diketahui mayoritas masyarakat mempunyai pengetahuan cukup dengan stigma terhadap ODHA sedang yaitu $55,2 \%$. Dan paling sedikit adalah masyarakat dengan pengetahuan baik memiliki stigma terhadap ODHA yang kurang yaitu 3,5\% .

Menurut Parut (2016) dalam penelitianya yang mengatakan bahwa pengetahuan yang kurang menimbulkan miskonsepsi mengenai HIV/AIDS. Hal ini akan menjadi penyebab munculnya stigma terhadap ODHA. Faktor lain yang mempengaruhi adalah mitos dan kepercayaan (agama). Ada hubungan yang signifikan antara pengetahuan mengenai HIV/AIDS dengan stigma terhadap ODHA, siswa dengan pengetahuan yang rendah memiliki stigma yang tinggi terhadap ODHA.

Berdasarkan penelitian yang dilakukan oleh Wisotowardono (2008), menyatakan bahwa ada hubungan yang signifikan antara pengetahuan HIV/AIDS rendah lebih berisiko untuk mengalami stigma di bandingkan dengan pelajar dengan tingkat pengetahuan tinggi.

Sejalan dengan penelitian Situmeang et al. (2017),prevalensi remaja yang mempunyai stigma terhadap ODHA sebesar $71,63 \%$, prevalensi remaja yang memiliki $p$ sebesar 49,10\%. Pengetahuan yang kurang 1,210 (95\%CI: 1,1491,273) kali lebih berisiko mempunyai stigma terhadap ODHA dibandingkan dengan pengetahuan yang cukup tentang HIV/AIDS setelah dikontrol keterpaparan media massa

Pada penelitian ini diuraikan bahwa masyarakat perlu mendapatkan pendidikan kesehatan tentang HIV/AIDS. Dengan adanya peningkatan pengetahuan maka stigma masyarakat terhadap ODHA dapat dikurangi. Sudah banyak contoh yang terjadi di kalangan masyarakat kita masih mempunyai pengetahuan kurang tentang HIV/AIDS maka lebih cenderung mempunyai 
stigma terhadap ODHA yang lebih tinggi, hal ini dikarenakan mereka takut akan tertular oleh penyakit yang dianggap sebagai penyakit yang mematikan tersebut.

\section{KESIMPULAN DAN SARAN}

Berdasarkan hasil penelitian, dapat disimpulkan bahwa ada hubungan antara tingkat pengetahuan tentang HIV/AIDS dengan stigma warga usia subur terhadap ODHA di Desa Pondok Kelor Kecamatan Paiton, Kabupaten Probolinggo, dan di harapkan tidak ada lagi stigma dan diskriminasi pada ODHA.

\section{REFERENSI}

Busza, J. (1999). Literature Review: Challenging HIV-Related Stigma and Discrimination in Southeast Asia: Past Successes and Future Priorities. $1-29$. http://www.nestragel.org/pdfs/HORIZONS_ paper.pdf

Kementerian Kesehatan Republik Indonesia. (2013). Prevention of mother-to-child HIV transmission. Project Inform Perspective.

Komisi penaggulangan AIDS (KPA). (2014). Buku pedoman program pencegahan HIV melalui transmisi seksual.

Mutahar, R., Najmah, \& Yenni. (2011). Determinants of Indonesian People Attitudes Towards People Living with HIV/AIDS (PLWHA). International Journal of Public Health Research, (Special issue), 218-222. http://pesquisa.bvsalud.org/ghl/resource/pt/ wprim-802651
Nyblade, L., MacQuarrie, K., Kwesigabo, G., Jain, A., Kajula, L., Philip, F., Tibesigwa, W., \& Mdwambo, J. (2009). Moving Forward: Tackling Stigma in a Tanzanian Community. 31.

Parut, A. (2016). Hubungan Pengetahuan Tentang HIV/AIDS dengan Stigma terhadap ODHA pada Siswa Kelas XI SMK VI Surabaya. Jurnal Ners Lentera, 4(2), 106-113.

PUSDIKLATNAKES KEMENKES RI. (2013). Modul Pelatihan Manajemen HIV/AIDS Bagi Tenaga Pendidik. UPT Pelatihan Kesehatan Masyarakat Murnajati.

Shaluhiyah, Z., Musthofa, S. B., \& Widjanarko, B. (2015). Stigma Masyarakat terhadap Orang dengan HIV/AIDS. Kesmas: National Public Health Journal, 9(4), 333. https://doi.org/10.21109/kesmas.v9i4.740

Situmeang, B., Syarif, S., \& Mahkota, R. (2017). Hubungan Pengetahuan HIV/AIDS dengan Stigma terhadap Orang dengan HIV/AIDS di Kalangan Remaja 15-19 Tahun di Indonesia (Analisis Data SDKI Tahun 2012). Jurnal Epidemiologi Kesehatan Indonesia, $\quad 1(2), \quad 35-43$. https://doi.org/10.7454/epidkes.v1i2.1803

Soekidjo Notoatmodjo. (2012). Promosi Kesehatan dan Perilaku Kesehatan (Edisi Revi). Rineka Cipta.

Wisotowardono, O. S. (2008). Hubungan Pengetahuan Tentang HIV/AIDS dengan Stigma ODHA di Kalangan Pelajar SMA di kota Surakarta. Yogyakarta. 